\title{
Postpartum supplementation of fermented ammoniated condensed whey improved feed efficiency and plasma metabolite profile
}

\author{
R. Caputo Oliveira, ${ }^{1}$ K. J. Sailer, ${ }^{1 *}$ H. T. Holdorf, ${ }^{1}$ C. R. Seely, ${ }^{1}$ R. S. Pralle, ${ }^{1}$ M. B. Hall, ${ }^{2}$ N. M. Bello, ${ }^{3}$ \\ and $\mathrm{H}$. M. White ${ }^{1} \dagger$ \\ ${ }^{1}$ Department of Dairy Science, University of Wisconsin-Madison 53706 \\ ${ }^{2}$ US Dairy Forage Research Center, USDA-Agricultural Research Service, Madison, WI 53706 \\ ${ }^{3}$ Department of Statistics, Kansas State University, Manhattan 66506
}

\section{ABSTRACT}

Postpartum dietary supplementation of gluconeogenic precursors may improve the plasma metabolite profile of dairy cows, reducing metabolic disorders and improving lactation performance. The objective of this trial was to examine the effects of supplementation with fermented ammoniated condensed whey (FACW) postpartum on lactation performance and on profile of plasma metabolites and hormones in transition dairy cows. Individually fed multiparous Holstein cows were blocked by calving date and randomly assigned to control (2.9\% dry matter of diet as soybean meal; $\mathrm{n}=20)$ or FACW (2.9\% dry matter of diet as liquid GlucoBoost, Fermented Nutrition, Luxemburg, WI; n = 19) dietary treatments. Treatments were offered from 1 to $45 \mathrm{~d}$ in milk (DIM). Cows were milked twice a day. Dry matter intake and milk yield were recorded daily and averaged weekly. Individual milk samples from 2 consecutive milkings were obtained once a week for component analysis. Rumen fluid was collected ( $\mathrm{n}=3$ cows/ treatment) at 4 time points per day at 7 and 21 DIM. Blood samples were collected within $1 \mathrm{~h}$ before feeding time for metabolite analysis and hyperketonemia diagnosis. Supplementation of FACW improved feed efficiency relative to control; this effect may be partially explained by a marginally significant reduction in dry matter intake from wk 3 to 7 for FACW-supplemented cows with no detected FACW-driven changes in milk yield, milk protein yield, and milk energy output compared with control. Also, there was no evidence for differences in intake of net energy for lactation, efficiency of energy use, energy balance, or body weight or body

Received August 8, 2018.

Accepted November 26, 2018.

${ }^{*}$ Current address: School of Veterinary Medicine, University of California-Davis 95616.

†Corresponding author: heather.white@wisc.edu condition score change from calving to 45 DIM between treatments. Supplementation of FACW shifted rumen measures toward greater molar proportions of propionate and butyrate, and lesser molar proportions of acetate and valerate. Cows supplemented with FACW had greater plasma glucose concentrations in the period from 3 to 7 DIM and greater plasma insulin concentrations compared with control. Plasma nonesterified fatty acid and $\beta$-hydroxybutyrate concentrations were decreased in cows supplemented with FACW compared with control cows in the period from 3 to 7 DIM. These findings indicate that FACW may have improved the plasma metabolite profile immediately postpartum in dairy cows. Additionally, supplementation of FACW resulted in improved feed efficiency as accessed by measures of milk output relative to feed intake.

Key words: transition cow, hyperketonemia, lactate

\section{INTRODUCTION}

The high energy demand for milk production coupled with low DMI results in mobilization of body reserves during the postpartum transition period. Excessive mobilization of fatty acids from adipose tissue can surpass complete hepatic oxidative capacity, leading to an excessive production of ketone bodies (Drackley, 1999; Herdt, 2000). Production of ketone bodies beyond oxidative capacities of tissues results in hyperketonemia (HYK), which is associated with negative effects on production, fertility, and health in dairy cows (McArt et al., 2012; Rutherford et al., 2016).

Postpartum dietary supplementation of anaplerotic and gluconeogenic substrates may improve the plasma metabolite profile in dairy cows during the postpartum transition period by increasing oxidative capacity and glucose production, thus reducing metabolic disorders and supporting improved lactation performance (White, 2015). Propionate, lactate, glycerol, and gluconeogenic AA are the primary hepatic gluconeogenic precursors in dairy cows (Aschenbach et al., 2010). GlucoBoost 
(Fermented Nutrition Corporation, Luxemburg, WI) is a fermented ammoniated condensed whey (FACW) product rich in ammonium lactate. Once in the rumen, lactate can be absorbed directly as lactate (Schwaiger et al., 2013; Qumar et al., 2016), fermented to propionate or acetate by lactate-utilizing bacteria (Baldwin et al., 1962), or converted to butyrate by protozoa (Brossard et al., 2004; Nagaraja and Titgemeyer, 2007), with the VFA subsequently absorbed. In addition to providing gluconeogenic precursors, additional supplies of propionate and lactate may also have an anaplerotic effect in regards to tricarboxylic acid (TCA) cycle intermediates in the liver (Aschenbach et al., 2010). The greater availability of intermediates of the TCA cycle in the liver may improve the total complete oxidation of acetyl CoA, resulting in decreased BHB formation (Aschenbach et al., 2010).

Our hypothesis was that provision of ammoniated lactate through FACW supplementation would increase the molar proportion of rumen propionate and provide additional lactate and propionate to the liver as gluconeogenic and anaplerotic precursors, resulting in an improved postpartum plasma metabolite profile and lactation performance. Our objectives were (1) to examine the effects of postpartum FACW supplementation on lactation performance and on the profile of plasma metabolites and hormones related to metabolic health in transition dairy cows and (2) to use a subset of rumen-fistulated cows to determine if patterns of rumen metabolite production reflected previous observations of FACW fermentation in vitro.

\section{MATERIALS AND METHODS}

\section{Animal Use, Treatments, and Handling}

All animal use and handling protocols were approved by the University of Wisconsin-Madison College of Agricultural and Life Sciences Animal Care and Use Committee. Multiparous Holstein cows $(\mathrm{n}=40)$ were housed in a tiestall facility and fed individually from $-28 \mathrm{~d}$ relative to the expected calving date to $45 \mathrm{DIM}$ at the University of Wisconsin-Madison Dairy Cattle Instruction and Research Center. Before -28 d relative to the expected calving date, cows were blocked by expected calving date and were randomly assigned to the treatments, defined as either control $(\mathrm{n}=20)$ or FACW $(\mathrm{n}=20)$. Cows that calved outside their expected calving week were reassigned to the block respective to their actual calving week. All cows were given ad libitum access to the same high-energy prepartum ration (1.69 $\mathrm{NE}_{\mathrm{L}} / \mathrm{kg}$ of diet $\mathrm{DM}$ ), which was formulated to meet the needs of late-gestation dry cows, plus a daily indi- vidual top-dress of $6 \mathrm{~kg}$ of cracked corn, adapted from previous experiments (Hippen et al., 1999; Pralle et al., 2015) to achieve postpartum HYK incidence consistent with industry averages. The incidence of HYK in the University of Wisconsin-Madison Emmons Blaine dairy herd averages $20 \%$ over the year (Rathbun et al., 2017), which is inconsistent with industry averages of HYK prevalence that have been reported as 15 to $22 \%$ from survey reports (Suthar et al., 2013; Santschi et al., 2016; Chandler et al., 2018) or the incidence (2 to 2.5 times the prevalence) reported previously as 40 to $60 \%$ (Oetzel, 2004; McArt et al., 2012). One cow assigned to the FACW treatment had uterine torsion at calving and was removed from the study. After calving, cows were offered ad libitum access to isonitrogenous lactating cow rations containing either $2.9 \% \mathrm{DM}$ of diet as soybean meal (control) or $2.9 \% \mathrm{DM}$ of diet as liquid FACW (GlucoBoost, Fermented Nutrition Corporation; $72.7 \%$ lactic acid, $55.5 \% \mathrm{CP}, \mathrm{pH}=6.5$ ) once daily at $0800 \mathrm{~h}$ until 45 DIM. Diets are presented in Table 1.

Whole-blood BHB was quantified cowside with the Precision Xtra meter (Abbott Diabetes Care, Alameda, CA) at 3, 5, 7, 9, 11, 14, 17, 21, 28, and 45 DIM, and more frequently if blood BHB exceeded $2.5 \mathrm{~m} M$. Cows with blood BHB $\geq 3.0 \mathrm{~m} M$, as indicated by the meter, were treated at the time of diagnosis with intravenous dextrose $(250 \mathrm{~mL}$; Phoenix Scientific Inc., St. Joseph, MO; $50 \%$ dextrose) and orally administered Propylene Advantage $(300 \mathrm{~mL} / \mathrm{d}$ for 3 to $5 \mathrm{~d}$; contains glycerin and propylene glycol; TechMix LLC, Stewart, MN). After diagnosis, cows remained under the supervision of a veterinarian, the herd staff, and the research team until blood BHB was $<1.2 \mathrm{mM}$. Other health incidents were diagnosed by a veterinarian and recorded.

\section{Sample Collection and Analysis}

Daily feed offered and refused was recorded by trained herd staff and daily intakes were determined by subtraction. Individual diet ingredients were sampled weekly. Samples were placed in a $55^{\circ} \mathrm{C}$ forced-air oven for $48 \mathrm{~h}$, ground to pass a 1-mm screen (Wiley Mill, Arthur H. Thomas, Philadelphia, PA), and composited by month. Chemical composition was evaluated at a commercial laboratory (Dairyland Labs, Arcadia, WI) and are presented in Table 1. Analyses included the following: DM determined by National Forage Testing Association method 2.1.4 with drying for $3 \mathrm{~h}$ at $105^{\circ} \mathrm{C}$ (Shreve et al., 2006); CP (AOAC International, 2012; method 973.18); ether extract (AOAC International, 2012; method 920.39); ash (AOAC International, 2012; method 942.05); ADF (AOAC International, 1996; method 973.18); NDF determined with heat-stable 
$\alpha$-amylase, sodium sulfite, and on an ash-free basis (Mertens, 2002); water-soluble carbohydrates (Derias, 1961); and starch determined according to the modified procedure from Bach Knudsen (1997) in which glucose was analyzed by YSI 2700 (YSI Biochemistry Analyzer, YSI Inc., Yellow Springs, OH).

Cows were milked twice daily at 0530 and $1730 \mathrm{~h}$. Milk yield of each cow was recorded daily from 1 to 45 DIM and averaged by week. Milk samples from an afternoon and subsequent morning milking were obtained weekly for milk composition and SCC analysis. Milk samples were preserved with 2-bromo-2-nitropropane-1,3-diol (Advanced Instruments Inc., Norwood, $\mathrm{MA}$ ), and sent to a commercial laboratory (AgSource, Menominee, WI) for determination of milk composition of fat, protein, and lactose by Fourier transform infrared spectrometry using the FOSS MilkoScan FT6000 (FOSS Analytical, Eden Prairie, MN) and milk SCC by
Fossomatic FC (FOSS Analytical). Component yields for the PM and AM were calculated by multiplying milk composition by the milk yield of that milking and summed. Previous lactation milk and fat yields were extracted from DairyComp 305 (Valley Agricultural Software, Tulare, CA).

Body condition scores were recorded at $-28 \mathrm{~d}$ relative to the expected calving date, and at 1 and 45 DIM by 2 trained individuals using a 5 -point scale with quarter-point increments (Wildman et al., 1982). Both scores were averaged within a time point for each cow. Body weights were also measured at $-28 \mathrm{~d}$ relative to the expected calving date, and at 1 and 45 DIM.

Daily intake of $\mathrm{NE}_{\mathrm{L}}$ from each cow was predicted with the NRC dairy model software (NRC, 2001) using the chemical composition of each ingredient within treatment diets and actual DMI, milk yield, milk solids, and $\mathrm{BW}$. The $\mathrm{NE}_{\mathrm{L}}$ requirement for maintenance

Table 1. Ingredient offered and chemical composition (means \pm SD) of prepartum, control, and fermented ammoniated condensed whey (FACW) lactation diets

\begin{tabular}{|c|c|c|c|}
\hline \multirow[b]{2}{*}{ Item } & \multirow[b]{2}{*}{ Prepartum } & \multicolumn{2}{|c|}{ Lactation } \\
\hline & & Control & FACW \\
\hline \multicolumn{4}{|l|}{ Ingredient offered, $\%$ of diet DM } \\
\hline Corn silage & $32.0 \pm 1.16$ & $31.5 \pm 0.98$ & $31.6 \pm 0.95$ \\
\hline Alfalfa silage & - & $23.1 \pm 1.66$ & $23.1 \pm 1.72$ \\
\hline Cottonseed, fuzzy & - & $6.0 \pm 0.23$ & $6.0 \pm 0.21$ \\
\hline Corn ground shell & - & $17.4 \pm 0.37$ & $17.3 \pm 0.44$ \\
\hline Soybean meal & $22.5 \pm 0.37$ & $9.7 \pm 0.20$ & $7.0 \pm 0.18$ \\
\hline Expeller soybean meal $^{1}$ & - & $4.9 \pm 0.10$ & $4.8 \pm 0.12$ \\
\hline Soy hulls & - & $3.9 \pm 0.08$ & $3.7 \pm 0.09$ \\
\hline $\mathrm{FACW}^{2}$ & - & - & $2.9 \pm 0.07$ \\
\hline $\operatorname{Mix}^{3}$ & $3.6 \pm 0.06$ & $3.5 \pm 0.07$ & $3.6 \pm 0.09$ \\
\hline Straw & $12.9 \pm 0.22$ & - & - \\
\hline Dry, cracked corn & $29.1 \pm 0.53$ & - & - \\
\hline \multicolumn{4}{|c|}{ Nutrient composition, $\%$ of diet DM } \\
\hline $\mathrm{DM}$ & $54.3 \pm 0.54$ & $54.9 \pm 1.32$ & $54.6 \pm 1.45$ \\
\hline $\mathrm{CP}$ & $16.1 \pm 0.92$ & $16.9 \pm 0.29$ & $17.1 \pm 0.21$ \\
\hline $\mathrm{ADF}$ & $17.1 \pm 0.28$ & $21.0 \pm 0.96$ & $20.7 \pm 0.83$ \\
\hline NDF & $24.6 \pm 0.36$ & $27.9 \pm 0.74$ & $27.4 \pm 1.01$ \\
\hline Starch & $34.9 \pm 1.27$ & $26.7 \pm 1.44$ & $26.3 \pm 1.07$ \\
\hline Ether extract & $2.7 \pm 0.08$ & $4.1 \pm 0.16$ & $4.5 \pm 0.16$ \\
\hline Ash & $7.7 \pm 0.36$ & $7.8 \pm 0.27$ & $7.9 \pm 0.19$ \\
\hline Water-soluble carbohydrates & $5.3 \pm 0.33$ & $4.4 \pm 0.61$ & $4.9 \pm 0.53$ \\
\hline $\mathrm{NFC}$ & $49.6 \pm 1.23$ & $44.7 \pm 0.48$ & $44.5 \pm 0.71$ \\
\hline $\mathrm{NE}_{\mathrm{L}}, 3 \times,{ }^{4} \mathrm{Mcal} / \mathrm{kg}$ of diet DM & $1.68 \pm 0.01$ & $1.67 \pm 0.01$ & $1.69 \pm 0.02$ \\
\hline
\end{tabular}

${ }^{1}$ Exceller meal (Quality Roasting Inc., Valders, WI).

${ }^{2}$ GlucoBoost (Fermented Nutrition Corporation, Luxemburg, WI; $72.7 \%$ DM lactic acid, $55.5 \% \mathrm{CP}, \mathrm{pH}=6.5$ ). ${ }^{3}$ Prepartum mix: $\mathrm{CaCO}_{3}(32.1 \%), \mathrm{CaH}_{4} \mathrm{P}_{2} \mathrm{O}_{8}(18.19 \%), \mathrm{CaSO}_{4}(14.7 \%), \mathrm{NaCl}(8.78 \%), \mathrm{MgO}(7.5 \%), \mathrm{MgSO}_{4}$ $(14.7 \%)$, mineral oil $(0.6 \%)$, selenium yeast 2000 (0.5\%, Prince Agri Products, Teaneck, NJ), Rumensin-90 (0.3\%, Elanco Animal Health, Greenfield, IN), biotin (0.3\%, DSM Nutritional Products, Belvidere, NJ), vitamin A $(278.4 \mathrm{kIU} / \mathrm{kg})$, vitamin $\mathrm{D}_{3}(84.1 \mathrm{kIU} / \mathrm{kg})$, and vitamin $\mathrm{E}(4,058 \mathrm{IU} / \mathrm{kg})$. Postpartum mix: $\mathrm{CaCO}_{3}$ $(33.5 \%), \mathrm{NaHCO}_{3}(30.5 \%)$, grease $(12.2 \%)$, Dical $21 \%$ (6.1\%, Sanimax, DeForest, WI), $\mathrm{MgO}(6.1 \%), \mathrm{NaCl}$ $(9.9 \%), \mathrm{ZnO}(0.3 \%), \mathrm{MnO}(0.3 \%), \mathrm{CuSO}_{4}(0.2 \%)$, selenium yeast $2000(0.1 \%$, Prince Agri Products), mineral oil $(0.1 \%), \mathrm{FeSO}_{4}(55,100 \mathrm{mg} / \mathrm{kg})$, EDDI $99 \%(5,510 \mathrm{mg} / \mathrm{kg}$, IodiTech Inc., Kansas City, $\mathrm{MO}), \mathrm{CoCO}_{3}(1,624$ $\mathrm{mg} / \mathrm{kg})$, vitamin A $(224.7 \mathrm{kIU} / \mathrm{kg})$, vitamin $\mathrm{D}_{3}(44.9 \mathrm{kIU} / \mathrm{kg})$, vitamin $\mathrm{E}(1,123 \mathrm{IU} / \mathrm{kg})$, Rumensin-90 $(0.2 \%$, Elanco Animal Health), and biotin (0.1\%, DSM Nutritional Products).

${ }^{4}$ Estimated with the NRC (2001) equations to calculate $\mathrm{NE}_{\mathrm{L}}$ at $3 \times$ maintenance. 
(Mcal/d) was calculated by the equation described by the NRC (2001): $0.08 \times$ BW $^{0.75}$. Energy content of milk (Mcal/d) was determined using the following equation as described by the NRC (2001): $[(0.0929 \times \%$ milk fat $)+(0.0563 \times \%$ milk true protein $/ 0.93)+(0.0395$ $\times \%$ milk lactose $)] \times$ milk yield from the day when milk was sampled. Weekly net energy balance (Mcal/d) was determined by subtracting the $\mathrm{NE}_{\mathrm{L}}$ requirement for maintenance and energy secreted in milk from $\mathrm{NE}_{\mathrm{L}}$ intake of the day when milk was sampled. Feed efficiency was assessed by different calculations: (1) milk yield divided by DMI of that day and averaged by week; (2) $\mathrm{NE}_{\mathrm{L}}$ output in milk (Mcal/d) divided by DMI; (3) $\mathrm{NE}_{\mathrm{L}}$ output in milk (Mcal/d) divided by intake of predicted dietary $\mathrm{NE}_{\mathrm{L}}(\mathrm{Mcal} / \mathrm{d})$ of the day when milk was sampled (efficiency of energy use); and (4) nitrogen content in milk protein (milk protein, $\mathrm{kg} / 6.38$ ) divided by intake of nitrogen (diet CP, $\% \times$ DMI, $\mathrm{kg} / 6.25$ ) of the day when milk was sampled (efficiency of nitrogen use).

Blood samples from the coccygeal vessels were obtained from all cows at $3,5,7,9,11,14,17,21,28$ and 45 DIM within $0100 \mathrm{~h}$ before feeding time for BHB, glucose, insulin, and nonesterified fatty acid (NEFA) quantification. Blood samples were collected in tubes containing potassium oxalate and $4 \%$ sodium fluoride (BD Vacutainer, Franklin Lakes, NJ) and in tubes without additives (BD Vacutainer). Samples for plasma measures were kept on ice in a cooler until centrifugation. Plasma was separated from blood after centrifuging at 2,000 $\times g$ at $4^{\circ} \mathrm{C}$ for $15 \mathrm{~min}$. Each plasma sample was aliquoted into tubes and stored at $-20^{\circ} \mathrm{C}$. Analysis for plasma NEFA concentration was performed using the Wako NEFA-HR(2) Microtiter Procedure kit (Wako Diagnostics, Richmond, VA). Plasma glucose concentration was quantified enzymatically using the Autokit Glucose (Wako Diagnostics). Plasma insulin concentration was analyzed in samples from $3,5,7,14$ and 28 DIM using the Mercodia Bovine Insulin Elisa Kit (Mercodia Immunoassays and Services, Uppsala, Sweden). Plasma BHB concentration was analyzed using the Stanbio BHB LiquiColor kit (Procedure number 2440-058, Stanbio Laboratory, Boerne, TX). Inter-assay coefficient of variations were 7.6, 3.6, 7.0, and $7.2 \%$ for plasma NEFA, glucose, insulin, and BHB, respectively. Intra-assay coefficients of variation never exceeded $10 \%$.

All cows were fitted with an individual rumination logger (HR-Tag, SCR Engineers Ltd., Netanya, Israel) on a neck collar to record rumination time via a builtin microphone. Time spent ruminating was recorded using a 2-min resolution and stored in 2-h intervals, as described and validated by Schirmann et al. (2009).
A subset of 3 rumen fistulated cows for each treatment were used for rumen fluid collection. Rumen fluid was collected from the cranial, ventral, and caudal areas of the rumen using a rumen probe and filtered through 4 layers of cheesecloth at $0200 \mathrm{~h}$ before and at 0130, 0500, and $0900 \mathrm{~h}$ after feeding time on 7 and 21 DIM. Immediately following collection, a portable $\mathrm{pH}$ meter (Accumet AP61, Fisher Scientific, Pittsburgh, $\mathrm{PA}$ ) was used to determine rumen fluid $\mathrm{pH}$. Aliquots (1 $\mathrm{mL}$ ) of rumen fluid were added to tubes containing 0.02 $\mathrm{mL}$ of $50 \% \mathrm{H}_{2} \mathrm{SO}_{4}$ for subsequent VFA analysis. Rumen organic acid concentrations were analyzed by HPLC as described by Weimer et al. (1991). Total organic acid values were the sum of acetate, propionate, butyrate, valerate, and total lactate; the dextrorotatory (D) and levorotatory $(\mathbf{L})$ forms of lactate were not differentiated by HPLC. Aliquots $(1 \mathrm{~mL})$ of rumen fluid were also acidified with $0.2 \mathrm{~mL}$ of $50 \%$ TCA solution and frozen until analysis for ammonia concentration as described by Bal et al. (2000).

\section{Statistical Analysis}

Continuous response variables were analyzed using general linear mixed models. For rumen variables with repeated measures (e.g., rumen $\mathrm{pH}$, ammonia-N, molar proportion of propionate, and so on), the linear predictor included the fixed effects of treatment, sampling day, and sampling time, as well as all interactions, and also the random effects of block and cow nested within treatment. For other response variables measured repeatedly over time (e.g., plasma metabolites, milk yield, DMI, and so on), the linear predictor included the fixed effects of treatment, time, and their interaction, as well as the random effects of block and cow nested within treatment. For response variables measured only once in each cow (e.g., BW and BCS change), the linear predictor included treatment as a fixed effect and block as a random effect. Analyses of studentized residuals were performed to check that model assumptions were reasonably met. Heterogeneous residual variances were identified for plasma concentration of BHB, as a function of HYK and non-HYK cows, and also for milk components, DMI, milk energy, rumination, SCC, total rumen VFA, rumen butyrate, rumen valerate, plasma glucose and insulin, and all calculations of feed efficiency as a function of time; all were fitted accordingly to meet model assumptions. In each case, the model with the best-fitting covariance structures was selected based on Bayesian information criteria and Akaike's information criteria, and used for further inference. In addition, the following data transformations were required to reasonably meet residual assumptions: the 
variable plasma insulin concentration was square root transformed, plasma NEFA concentration was fourthroot transformed, and feed efficiency and SCC were natural log-transformed.

Hyperketonemia was defined on an individual cow as a binary response based on plasma BHB concentrations $\geq 1.2 \mathrm{mM}$ (McArt et al., 2012; Pralle et al., 2018; Sailer et al., 2018) in at least one of $3,5,7,9,11,14$, and 17 DIM plasma samples. The probability of HYK was estimated using a generalized linear mixed model that assumed a binomial distribution of the response and was fitted with a logit link function. The linear predictor included treatment as a fixed effect and block as a random effect.

All statistical models were fitted using the GLIMMIX procedure of SAS (version 9.4, SAS Institute Inc., Cary, NC). When treatment by time interactions were relevant, treatment differences were evaluated within each time point (i.e., simple-effect comparisons). Also, contrasts were tailor-built to further assess questions of interest. All post-hoc simple-effect comparisons and contrasts were Bonferroni adjusted to prevent inflation of type I error due to multiplicity (Bello and Renter, 2018). Given the established importance of plasma metabolite concentrations during the postpartum transition period, sampling intensity was greater from 3 to 17 DIM. Plasma BHB dynamics during the first week (3 to 7 DIM) postpartum represent changes in metabolism and result in increased risk of postpartum diseases and other negative herd-level outcomes when compared with periods after the first week (McArt et al., 2012); therefore, a preplanned contrast was performed to identify treatment effects on plasma metabolite concentrations for the duration of the period from 3 to 7 DIM.

Hours relative to feeding time and DIM for rumen samples are presented as arithmetic means \pm standard deviation. Estimated treatment means are presented as least square estimates and $95 \%$ confidence intervals in the observed data scale, following back-transformation (if appropriate). Means were considered significantly different when $P \leq 0.05$ and marginal evidence for difference when $0.05<P \leq 0.10$ for continuous variables or $0.05<P \leq 0.20$ for binary variables, given their less informative nature for any fixed sample size.

\section{RESULTS}

No evidence was observed of any differences between treatments $(P>0.61)$ in the number of lactations or previous lactation milk yield and fat yield of the cows on study. Estimated BCS for control cows did not differ significantly from FACW cows at $-28 \mathrm{~d}$ relative to the expected calving date [3.42 BCS units (95\% CI: 3.16,
$3.67)$ vs. 3.43 BCS units (95\% CI: 3.19, 3.68), respectively; $P=0.86$ ], nor did cow BW $[786.8 \mathrm{~kg}(95 \% \mathrm{CI}$ : $744.90,828.71)$ vs. $770.4 \mathrm{~kg}(95 \%$ CI: $731.36,809.38)$, respectively; $P=0.46]$. At calving, BCS [3.30 BCS units (95\% CI: $3.12,3.48)$ vs. 3.30 BCS units $(95 \%$ CI: $3.14,3.47)]$ and BW [748.5 kg (95\% CI: 704.40, 792.69) vs. $741.9 \mathrm{~kg}(95 \%$ CI: 701.61, 782.16)] for cows assigned to control and FACW treatments, respectively, also did not differ significantly $(P>0.79)$ between treatment groups.

For milk, milk fat, milk protein, and milk lactose yield, there was no evidence of any treatment differences (Table 2; $P>0.54$ ), or for MUN or milk energy output (Table $2 ; P>0.21$ ). The dietary $\mathrm{NE}_{\mathrm{L}}$ content, predicted with the NRC dairy model software, was greater $(P<0.01)$ in the FACW diet compared with the control diet. The effect of FACW supplementation on DMI differed with DIM (interaction $P<0.01$ ), with a marginally significant reduction $(P=0.08$, Figure 1$)$ from wk 3 to 7 postpartum compared with control. A similar interaction was observed when milk yield was corrected for DMI $(P<0.01)$, whereby supplementation of FACW increased $(P=0.03)$ milk yield per unit of DMI from wk 3 to 7 postpartum compared with control (Figure 1). In addition, there was marginal evidence for greater efficiency of nitrogen use $(P=0.07)$ and milk energy output per unit of DMI $(P=0.09)$ in FACW cows compared with control cows (Table 2). In turn, there was no evidence for any treatment effect on efficiency of energy use $(P=0.45)$, predicted $\mathrm{NE}_{\mathrm{L}}$ intake $(P=0.22)$, calculated energy balance $(P=0.35)$, or BW and BCS change $(P>0.19)$ from calving to 45 DIM (Table 2).

Actual collection of rumen fluid was at (arithmetic mean \pm SD) $0152 \pm 0013 \mathrm{~h}$ before and at $0140 \pm 0013$ $\mathrm{h}, 0539 \pm 0010 \mathrm{~h}$, and $0935 \pm 0012 \mathrm{~h}$ after feeding time on $7.2 \pm 2.0$ and $21.2 \pm 2.0$ DIM. The effect of FACW supplementation on ruminal molar proportion of acetate and propionate differed with DIM (interaction $P$ $<0.01)$, with a decrease $(P=0.02$, Figure 2$)$ in acetate and marginally significant increase in propionate $(P=$ 0.09 , Figure 2 ) at 7 DIM only; together, this resulted in a decreased $(P=0.03)$ acetate to propionate ratio at 7 DIM (Table 3; Figure 2). Supplementation with FACW increased $(P=0.03)$ the ruminal molar proportion of butyrate at 7 and 21 DIM and decreased $(P=0.02)$ the ruminal molar proportion of valerate at 7 DIM compared with control cows (Table 3; Figure 2). There was no evidence for any treatment difference in total ruminal organic acid concentration $(P=0.18$; Table $3)$. For rumen ammonia-N, a 3 -way interaction between treatment, day, and sampling time $(P=0.06)$ was explained by a marginally significant increase $(P=0.10)$ 
Table 2. Estimated mean (95\% CI) milk yield, milk component yield, milk composition, milk energy, DMI, feed efficiency, energy balance and BW and BCS change in dairy cows treated with control or fermented ammoniated condensed whey (FACW $)^{1}$

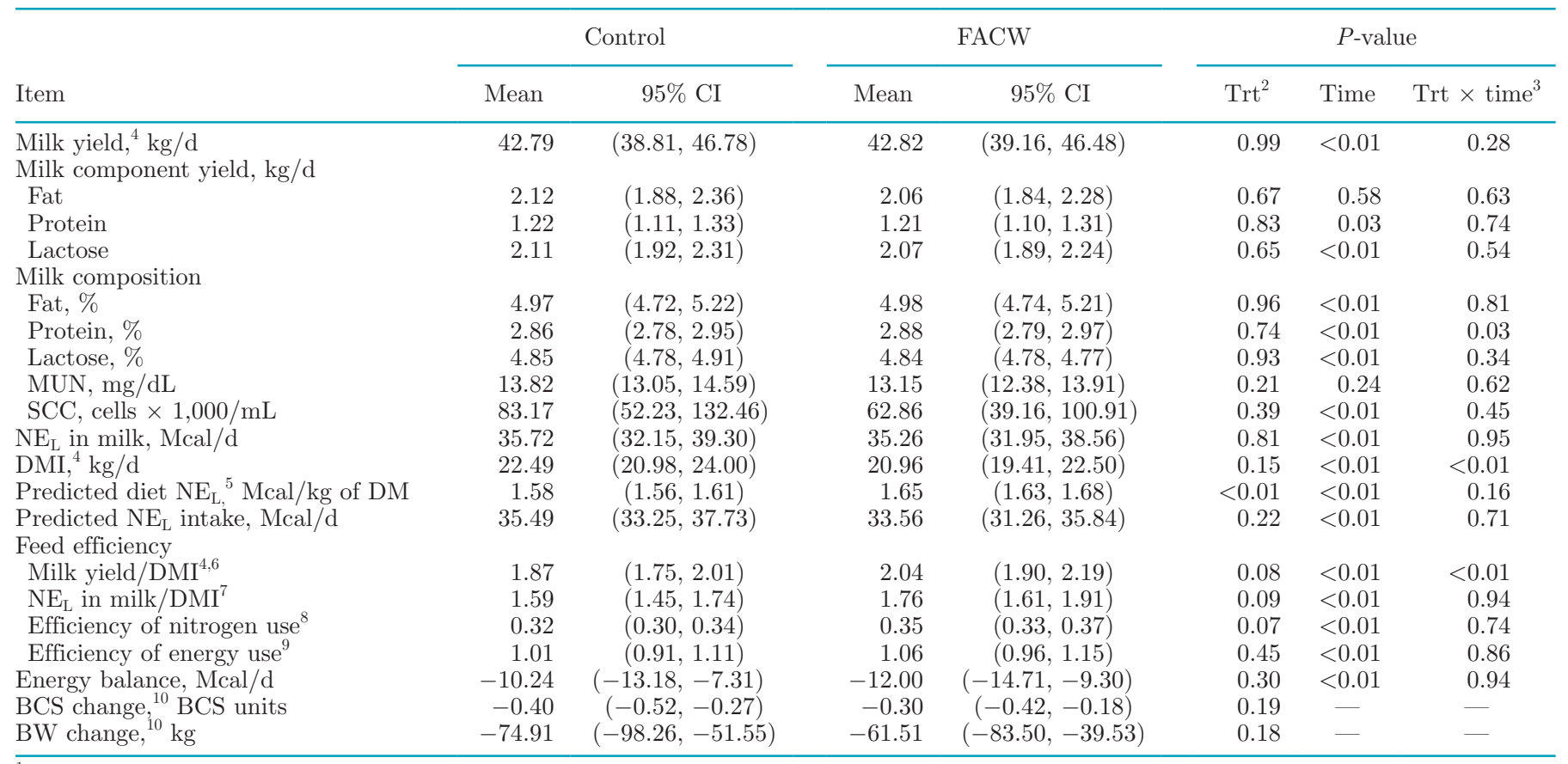

${ }^{1}$ Treatments: FACW $(\mathrm{n}=19)$, containing $2.9 \%$ DM of diet in a liquid FACW (GlucoBoost, Fermented Nutrition Corporation, Luxemburg, WI; $72.7 \%$ lactic acid, $55.5 \% \mathrm{CP}$ ); or control $(\mathrm{n}=20)$, containing the equivalent percent as soybean meal from calving to 45 DIM.

${ }^{2}$ Treatment.

${ }^{3}$ Interaction between treatment $\times$ time.

${ }^{4}$ Data from calving to 45 DIM, averaged weekly.

${ }^{5}$ Predicted with the NRC dairy model software (NRC, 2001) using the chemical composition of each ingredient within treatment diets and actual DMI, milk yield, milk solids, and BW.

${ }^{6}$ Milk yield $(\mathrm{kg} / \mathrm{d})$ divided by DMI $(\mathrm{kg} / \mathrm{d})$.

${ }^{7} \mathrm{NE}_{\mathrm{L}}$ output in milk (Mcal/d) divided by DMI $(\mathrm{kg} / \mathrm{d})$.

${ }^{8}$ Nitrogen content in milk protein (milk protein, $\mathrm{kg} / 6.38$ ) divided by intake of nitrogen (diet CP, $\% \times$ DMI, $\mathrm{kg} / 6.25$ ) of the day when milkwas sampled.

${ }^{9} \mathrm{NE}_{\mathrm{L}}$ output in milk (Mcal/d) divided by intake of predicted dietary $\mathrm{NE}_{\mathrm{L}}(\mathrm{Mcal} / \mathrm{d})$ of the day when milk was sampled.

${ }^{10} \mathrm{BCS}$ and BW change from 1 to 45 DIM.

from $4.2 \mathrm{mg} / \mathrm{dL}(95 \% \mathrm{CI}:-2.08,10.47)$ to $15.6 \mathrm{mg} / \mathrm{dL}$ (95\% CI: 9.32, 21.88) for FACW compared with control at $-0200 \mathrm{~h}$ relative to feeding time at 7 DIM (Table 3 ). The effect of FACW supplementation on rumen $\mathrm{pH}$ differed with DIM (interaction $P=0.02$ ), with a decrease $(P=0.05$, Figure 2$)$ at 7 DIM only. Treatment had no significant effect $(P=0.85)$ on the time cows spent ruminating per day [431.3 min (95\% CI: 383.95, 479.02) vs. 425.8 min (95\% CI: 361.51, 477.62) for control and FACW, respectively].

No treatment effects were detected on plasma glucose concentration during most of the experimental period, except between $\mathrm{d} 3$ and 7 postpartum (interaction treatment $\times$ time, $P=0.04$ ); during this initial postpartum period, FACW cows showed greater $(P=0.02$; Figure 3) plasma glucose compared with control cows. In addition, the detected treatment $\times$ time interaction was explained by different dynamics of plasma glucose over time for each of the treatments (Figure 3). Specifically, for control cows, plasma glucose concentration increased $(P<0.01)$ by 45 DIM compared with previous time points; this was not apparent in FACW cows. Moreover, cows supplemented with FACW had reduced $(P<0.01)$ plasma glucose at 11 DIM compared with 3 DIM and increased $(P<0.01)$ again at 28 DIM compared with 11 DIM.

For plasma BHB, we identified a treatment $\times$ time interaction $(P<0.01$; Figure 3$)$ due to a decreased $(P$ $=0.02$ ) plasma BHB for FACW cows compared with control cows between d 3 and 7 postpartum. In addition, different time dynamics of plasma BHB concentration was apparent for each of the treatments. For control cows, plasma BHB concentration was decreased $(P<$ 0.02 ) at 45 DIM relative to 3 to 28 DIM. Conversely, FACW cows showed no significant changes in BHB concentration over the period of observation $(P>0.27)$. 

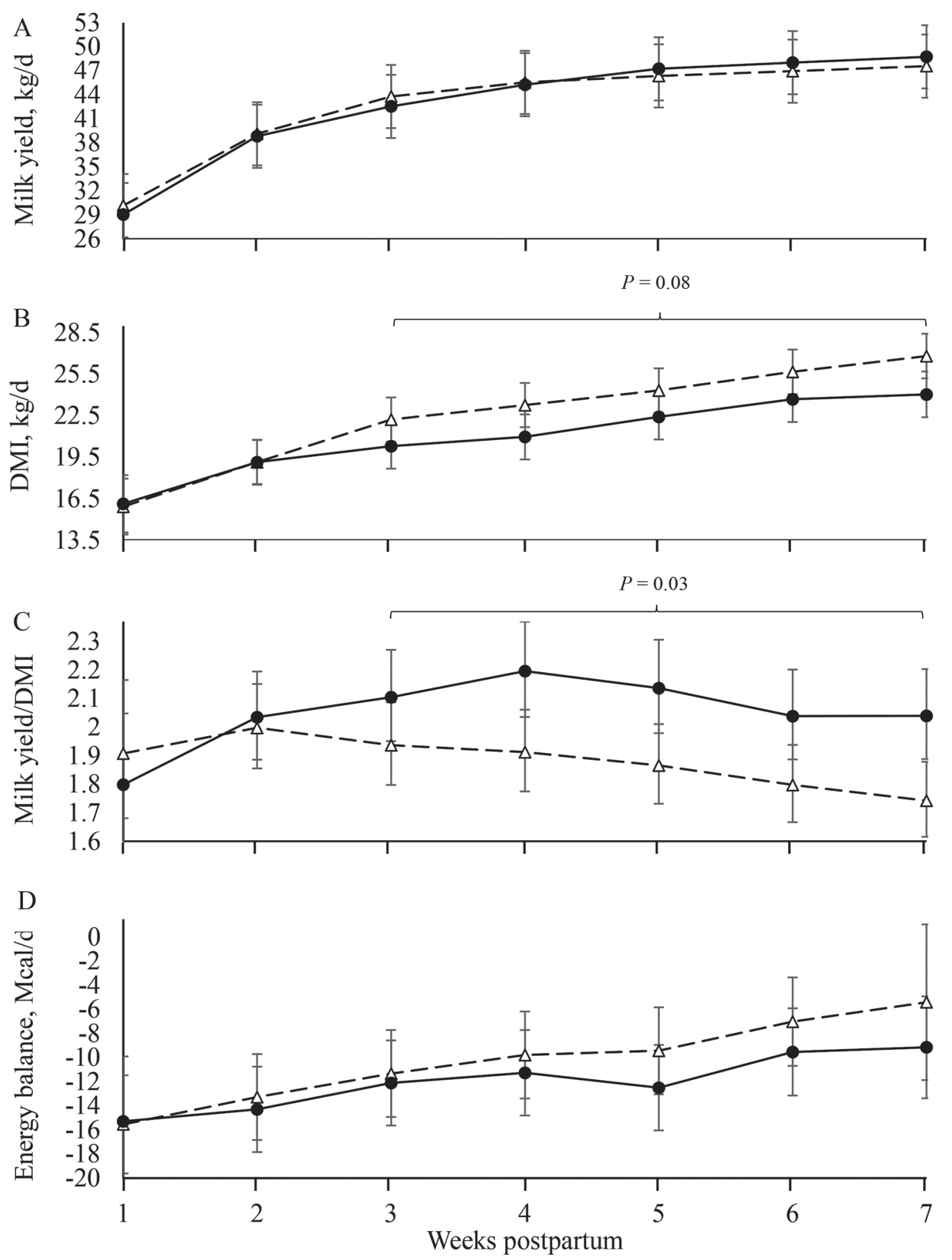

Figure 1. Estimated mean $\pm 95 \%$ CI milk yield (panel A), DMI (panel B), milk yield $(\mathrm{kg} / \mathrm{d}$ ) divided by DMI (kg/d; panel C), and energy balance (panel D) in dairy cows treated with control (open triangles) or fermented ammoniated condensed whey (FACW; closed circles) at wk 1 to 7 postpartum. Treatments: FACW $(\mathrm{n}=19)$, containing $2.9 \% \mathrm{DM}$ of diet in a liquid fermented ammoniated condensed whey (GlucoBoost, Fermented Nutrition Corporation, Luxemburg, WI; $72.7 \%$ lactic acid, $55.5 \% \mathrm{CP})$; or control $(\mathrm{n}=20)$, containing the equivalent DM percent as soybean meal from calving to 45 DIM. Panel A: treatment, $P=0.99$, and interaction treatment $\times$ time, $P=0.28$. Panel B: interaction treatment $\times$ time, $P<0.01$. Panel C: interaction treatment $\times$ time, $P<0.01$. Panel D: treatment, $P=0.30$, and interaction treatment $\times$ time, $P$ $=0.94$. Brackets represent Bonferroni-adjusted contrasts between treatment means across the 3- to 7-wk period. 


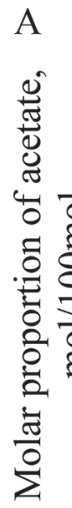

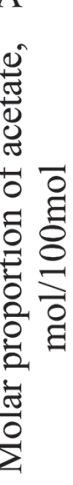

55

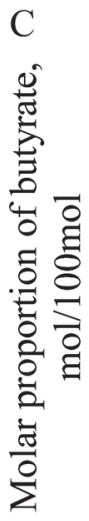

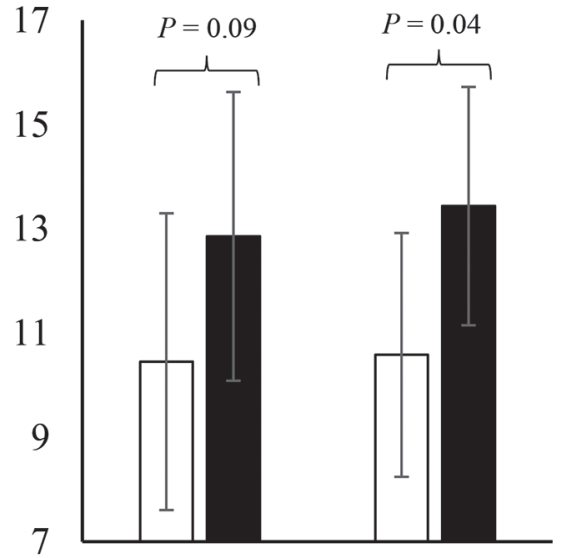

E

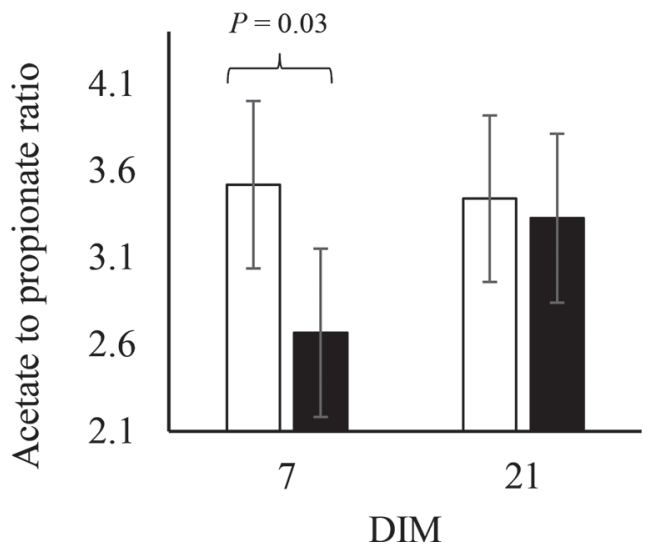

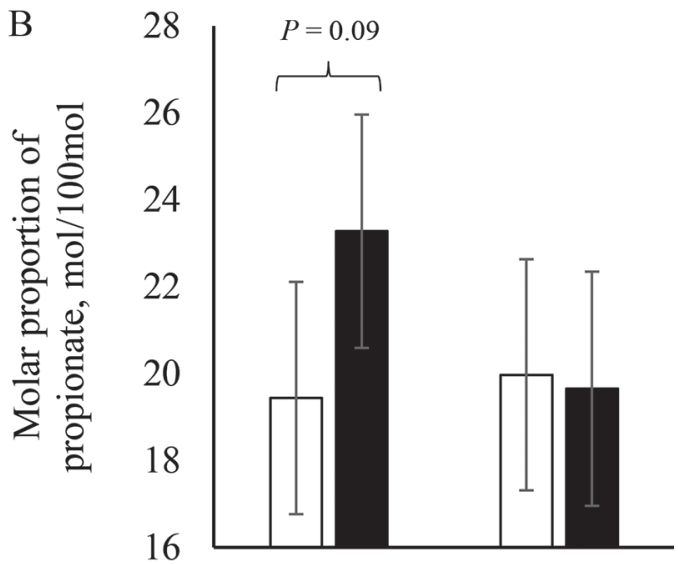

$\mathrm{D}$

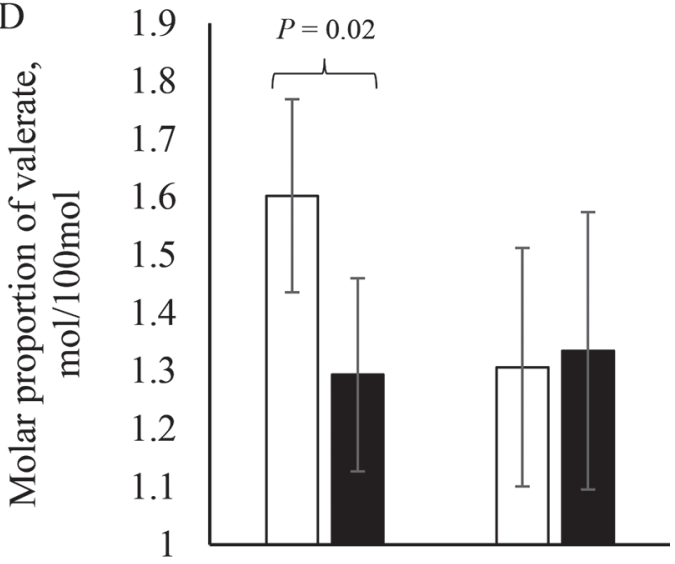

F

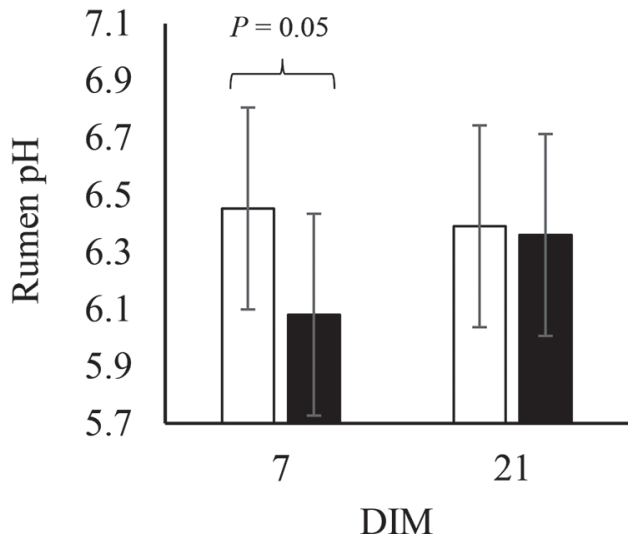

Figure 2. Estimated mean $\pm 95 \%$ CI molar proportion of acetate (panel A), molar proportion of propionate (panel B), molar proportion of butyrate (panel C), molar proportion of valerate (panel D), acetate to propionate ratio (panel E), and rumen $\mathrm{pH}$ (panel F) in dairy cows treated with control (open bars) or fermented ammoniated condensed whey (FACW; closed bars) at 7 and 21 DIM. Treatments: FACW ( $\mathrm{n}=$ 19), containing $2.9 \%$ DM of diet in a liquid fermented ammoniated condensed whey (GlucoBoost, Fermented Nutrition Corporation, Luxemburg, WI: $72.7 \%$ lactic acid, $55.5 \% \mathrm{CP}$ ); or control $(\mathrm{n}=20)$, containing the equivalent DM percent as soybean meal from calving to 45 DIM. Panel A: interaction treatment $\times$ time, $P<0.01$. Panel B: interaction treatment $\times$ time, $P<0.01$. Panel C: treatment, $P=0.03$, and interaction treatment $\times$ time, $P=0.52$. Panel D: interaction treatment $\times$ time, $P=0.05$. Panel E: interaction treatment $\times$ time, $P<0.01$. Panel F: interaction treatment $\times$ time, $P=0.02$. Brackets represent Bonferroni-adjusted simple-effect comparisons between treatment means within DIM.

For plasma NEFA, an interaction between treatment and time $(P<0.01)$ was explained by a marginally significant reduction $(P=0.08)$ in plasma NEFA be- tween $\mathrm{d} 3$ and 7 postpartum for FACW cows compared with control cows (Figure 3). As with other blood metabolites, this interaction also showed different time 
dynamics of plasma NEFA concentration for each of the treatments. For FACW cows, plasma NEFA concentration showed a reduction $(P<0.001)$ from 3 to 21 DIM, whereas the control cows only showed a reduction $(P<0.01)$ in plasma NEFA between 9 and 21 DIM in that same time frame. Supplementation of FACW increased $(P=0.03)$ overall plasma insulin concentration throughout the study period of 3 to 28 DIM (Figure 4).

All cases of HYK developed by 17 DIM. Incidence of HYK was estimated at $60.0 \%$ (95\% CI: 17.06, 91.62) and $36.8 \%$ (95\% CI: 13.07, 69.34), for control and FACW cows, respectively (Figure $5 ; P=0.16$ ). The proportion of cows that experienced $\mathrm{BHB} \geq 3.0 \mathrm{~m} M$, as measured by the Precision Extra meter (Abbott Diabetes Care) and that were subsequently treated for HYK, was not significantly different $(P=0.59)$ between treatments (2/20 vs. $3 / 19$ for control and FACW cows, respectively). Only 1 cow in each treatment experienced clinical ketosis, defined as BHB $\geq 3.0 \mathrm{~m} M$, as quantified by the laboratory assay (Stanbio BHB LiquiColor kit, Stanbio Laboratory).

\section{DISCUSSION}

The primary objectives of this trial were to examine the effect of FACW supplementation on lactation performance as well as on plasma metabolites and insulin as related to metabolic health in transition dairy cows. We hypothesized that the metabolism of the FACW product would provide gluconeogenic and anaplerotic precursors that are essential during early lactation, resulting in an improved postpartum plasma metabolite profile and lactation performance. Given the objectives of this experiment, it was important that the postpartum plasma metabolite profile and incidence of HYK be consistent with what is observed across dairy farms in the region and country. Prevalence of HYK in multiparous Holstein cows has been reported as 15 to $22 \%$ from survey reports (Suthar et al., 2013; Santschi et al., 2016; Chandler et al., 2018). This is consistent with the postpartum HYK incidence (2 to 2.5 times the prevalence) reported previously as 40 to $60 \%$ (Oetzel, 2004; McArt et al., 2012). The incidence of HYK in the University of Wisconsin-Madison Emmons Blaine dairy herd averages $20 \%$ over the year (Rathbun et al., 2017). Feeding more energy in a prepartum ration to all cows resulted in a HYK incidence of $60 \%$ in the control group, which is similar to that reported by McArt et al. (2012). Overfeeding energy prepartum is a known contributor to postpartum HYK (Douglas et al., 2006; Janovick et al., 2011), and although this nutritional model allows examination of the effects of interventions on cows with a given HYK incidence, it does not necessarily represent all causes of elevated HYK incidence. 
As a nutrient source, FACW product is a high-energy feed based on lactate content, but is also high in CP with $55.5 \% \mathrm{CP}$ on a DM basis, largely in the form of the nonprotein $\mathrm{N}$ associated with ammonium lactate. Regarding its value as a protein source, there has been no evidence that isonitrogenous diets containing either FACW or soybean meal yielded different in vitro growth of mixed ruminal microbes (Wagner et al., 2018). Our results are in agreement with the previous continuous culture trial in which diets containing liquid FACW decreased the molar percentage of acetate and increased those of butyrate, propionate, and ammonia- $\mathrm{N}$ production compared with isonitrogenous diets containing soybean meal (Wagner et al., 2018). Megasphaera elsdenii, a major lactate-utilizing bacterium, converts L-lactate to propionate and D-lactate to either L-lactate
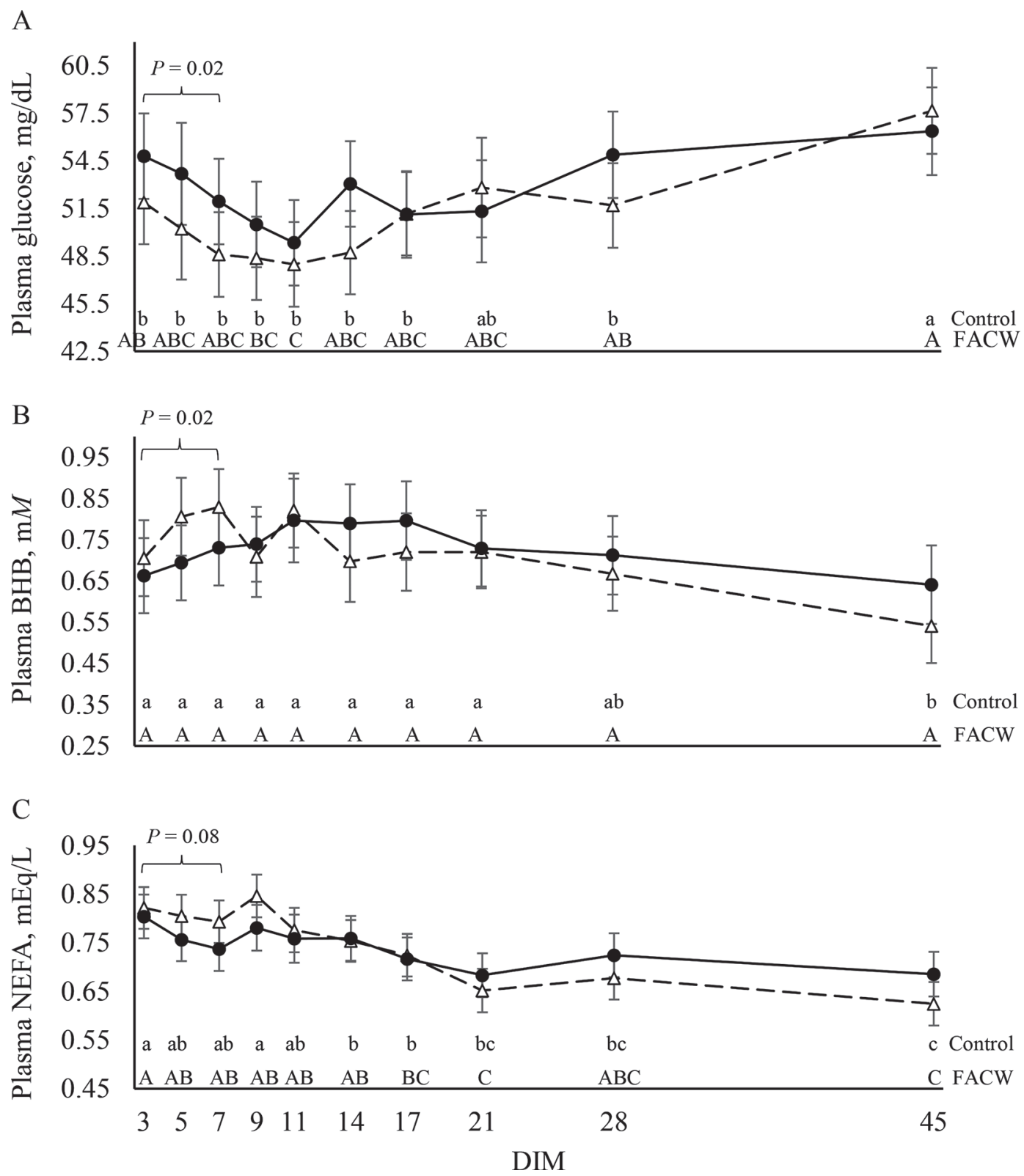

Figure 3. Estimated mean $\pm 95 \%$ CI plasma glucose (panel A), BHB (panel B), and nonesterified fatty acids (NEFA; panel C) in dairy cows treated with control (open triangles) or fermented ammoniated condensed whey (FACW; closed circles) at 3, 5, 7, 9, 11, 14, 17, 21, 28, and 45 DIM. Treatments: FACW $(\mathrm{n}=19)$, containing $2.9 \% \mathrm{DM}$ of diet in a liquid fermented ammoniated condensed whey (GlucoBoost, Fermented Nutrition Corporation, Luxemburg, WI; $72.7 \%$ lactic acid, $55.5 \% \mathrm{CP}$ ); or control $(\mathrm{n}=20)$, containing the equivalent DM percent as soybean meal from calving to 45 DIM. Panel A: interaction treatment $\times$ time, $P=0.04$. Panel B: interaction treatment $\times$ time, $P<0$. 01. Panel C: interaction treatment $\times$ time, $P<0.01$. Brackets represent pre-planned contrasts between FACW and control for the first week postpartum $(3$ to 7 DIM). Letters along the $\mathrm{x}$-axis represent differences in days postpartum for control (lowercase) or FACW (uppercase). 


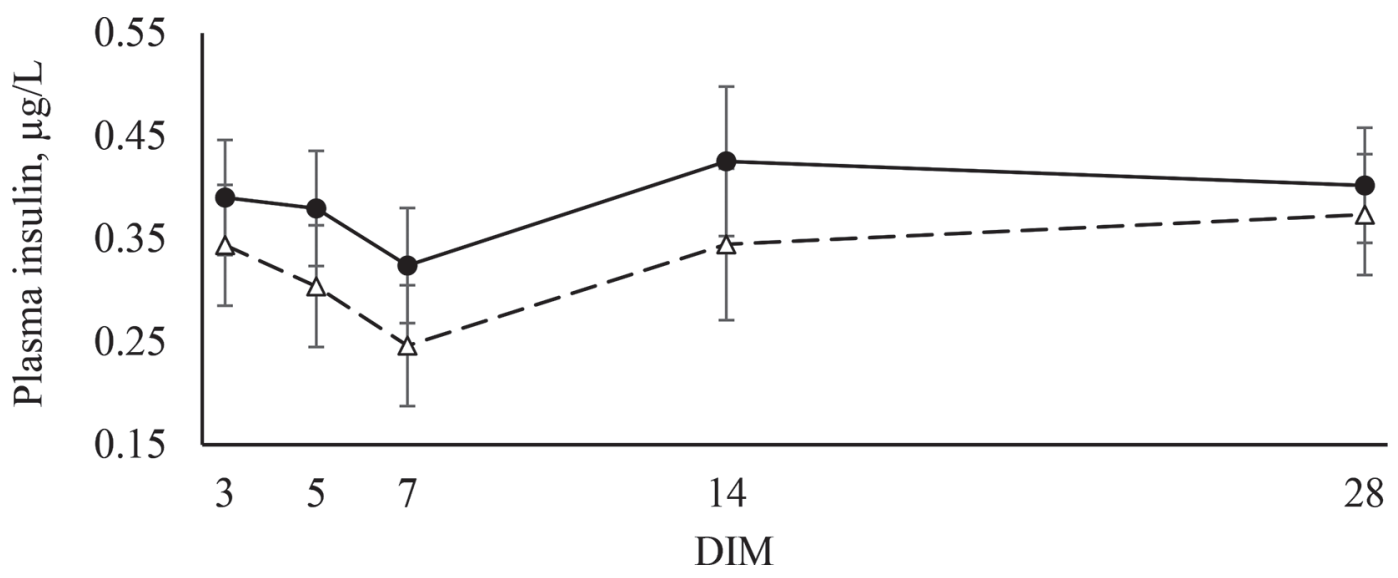

Figure 4. Estimated mean $\pm 95 \%$ CI plasma insulin in dairy cows treated with control (open triangles) or fermented ammoniated condensed whey (FACW; closed circles) at 3, 5, 7, 14, and 28 DIM. Treatments: FACW ( $\mathrm{n}=19)$, containing $2.9 \%$ DM of diet in a liquid fermented ammoniated condensed whey (GlucoBoost, Fermented Nutrition Corporation, Luxemburg, WI; $72.7 \%$ lactic acid, $55.5 \% \mathrm{CP})$; or control $(\mathrm{n}=20)$, containing the equivalent DM percent as soybean meal from calving to 45 DIM. Treatment, $P=0.03$, and interaction treatment $\times$ time, $P=0.61$.

or pyruvate, which is further metabolized to other VFA (Hino and Kuroda, 1993; Prabhu et al., 2012). The ammoniated lactate product fed in this trial is racemic, composed of equal proportions of $\mathrm{D}$ and $\mathrm{L}$ forms of lactate (Wagner et al., 2018). The shift in fermentation toward increased molar proportions of propionate and butyrate observed in the current trial may be explained by an increase in lactate-utilizing bacteria fermenting lactate preferentially to propionate, and by stimulation of protozoa, primarily producing butyrate (Newbold et al., 1987; Brossard et al., 2004). The preferential conversion of lactate to propionate would be enhanced by

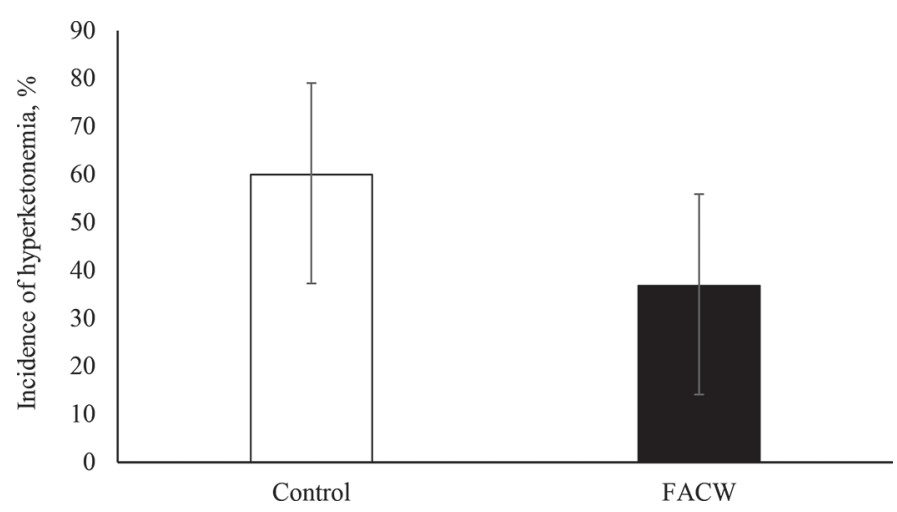

Figure 5. Estimated mean $\pm 95 \%$ CI incidence of hyperketonemia in dairy cows treated with control (open bar) or fermented ammoniated condensed whey (FACW; closed bar). Incidence of hyperketonemia was defined as a binary response based on plasma BHB concentrations $>1.2 \mathrm{~m} M$ in at least one of the plasma samples collected at 3 , $5,7,9,11,14$, and 17 DIM. Treatments: FACW $(\mathrm{n}=19)$, containing $2.9 \% \mathrm{DM}$ of diet in a liquid fermented ammoniated condensed whey (GlucoBoost, Fermented Nutrition Corporation, Luxemburg, WI; $72.7 \%$ lactic acid, $55.5 \% \mathrm{CP}$ ); or control $(\mathrm{n}=20)$, containing the equivalent DM percent as soybean meal from calving to 45 DIM. Treatment, $P=0.16$. the starch level in the lactating cow diets (Baldwin et al., 1962). The increase in rumen ammonia-N for cows supplemented with FACW was expected because of the nature of the product which contains high amount of NPN. In another study, lactate concentrations were greater in treatments containing FACW until $0100 \mathrm{~h}$ postdosing, but largely disappeared after that (Wagner et al., 2018). The transient nature of lactate in the rumen as it is converted to other microbial products offers an explanation for the absence of a significant effect of FACW on rumen lactate concentration in the current trial, given that the first rumen sample collected was about $0130 \mathrm{~h}$ after feeding. Besides lactate being fermented to other short-chain fatty acids, it may also be absorbed directly by the rumen epithelial wall through monocarboxylate transporter-1 (Aschenbach et al., 2011); however, lactate absorption seems to be substantial only after a period of adaptation to a highly fermentable diet (Schwaiger et al., 2013; Qumar et al., 2016).

The relative depression of rumen $\mathrm{pH}$ with FACW supplementation at 7 DIM but not at 21 DIM compared with control could be related to the aforementioned adaptation period necessary for lactate absorption by the rumen epithelium (Schwaiger et al., 2013; Qumar et al., 2016). However, this differs from a continuous culture trial in which there was no evidence for an effect of FACW on rumen pH (Wagner et al., 2018). It is worth noting that their continuous culture trial did not account for potential differences in DMI caused by FACW, nor for the effects of the absorptive capacity of organic acids by rumen epithelial cells, which is a key determinant of ruminal $\mathrm{pH}$ (Resende Júnior et al., 2006; Penner et al., 2009a,b). Additionally, the decreased DMI of FACW-supplemented cows at 21 DIM 
could also have lessened the effect of the diet on rumen $\mathrm{pH}$ as the animals consumed less fermentable substrate. Rumen $\mathrm{pH}$ was above 5.8 at all sampling times within sampling days for all cows. The risk of SARA increases when ruminal $\mathrm{pH}$ drops below 5.8 for more than 5.2 h/d (Zebeli et al., 2008) or below 5.6 for more than 3 h/d (Plaizier et al., 2008). When considered together with the lack of evidence for negative effects of FACW on rumen $\mathrm{pH}$ in the in vitro trial (Wagner et al., 2018), the current results support that supplementation of FACW, as performed in the current study, would not increase the likelihood of dairy cows developing SARA.

It is possible that the greater and more rapid availability of anaplerotic metabolites such as propionate and lactate to the liver in cows supplemented with FACW compared with control may have reduced DMI, consistent with the hepatic oxidation theory (Allen et al., 2009). Propionate and lactate might have increased hepatic oxidation of acetyl CoA during meals, decreasing meal size or frequency or both, which may have affected the total daily DMI as demonstrated previously with postruminal infusions of propionate (GualdrónDuarte and Allen, 2017, 2018; Maldini and Allen, 2018) and lactate (Gualdrón-Duarte and Allen, 2018).

The FACW effect of reducing DMI, combined with no detected effects on milk production and milk energy output, may have mediated the greater milk production and milk energy output per unit of DMI. Marginal evidence indicated that cows supplemented with FACW had greater efficiency of nitrogen utilization as milk protein, which may suggest a sparing of AA from gluconeogenesis in the liver or an insulinogenic effect or both to increase extraction efficiency of AA by the mammary gland of FACW cows (Mackle et al., 2000; Arriola Apelo et al., 2014). It was not the objective of the study to investigate the partitioning of nitrogen by treatments; thus, more research examining flux and origin of carbons for gluconeogenesis and mammary gland extraction of AA to elucidate the mechanism(s) underlying it is warranted.

Despite improved feed efficiency in FACW-supplemented cows, no evidence was observed of differences in BW and BCS change from calving to 45 DIM between treatments. It is widely accepted that the digestibility of diets fed to dairy cows is reduced with increasing feed intake (Tyrrell and Moe, 1975; NRC, 2001). Within the current study, in terms of energy intake, the lower DMI in FACW-supplemented cows may have been partially compensated by a potentially greater digestibility of the FACW diet compared with control. This is supported by the increased predicted (NRC model) $\mathrm{NE}_{\mathrm{L}}$ per unit of DM available for milk production in the FACW diet. Using this predicted dietary $\mathrm{NE}_{\mathrm{L}}$ per unit of $\mathrm{DM}$ to estimate daily $\mathrm{NE}_{\mathrm{L}}$ intake did not result in differences in energy intake between treatments, which could partially explain the inability to detect differences in BCS and BW change across the study. Furthermore, the decrease in adipose triglyceride mobilization postpartum, as indicated by reduced plasma NEFA between 3 and $7 \mathrm{~d}$ postpartum, paired with the lack of evidence of increased plasma NEFA as DMI decreased, further support that the energy and glucose required to support milk production were met at a lower intake by the FACW supplemented ration.

Supplementation of FACW provided gluconeogenic precursors, which may have been available to support endogenous glucose production. Circulating glucose concentrations are reflective of both hepatic glucose production and nonhepatic tissue utilization; therefore, plasma glucose concentrations cannot be used alone to indicate glucose production. When considered together, increased plasma glucose during the immediate postpartum period (3 to 7 DIM) and the lack of evidence of reduced milk yield and lactose production suggest a potential for increased glucose production with FACW supplementation. Further research examining hepatic gluconeogenic pathways is needed to more completely understand the effect of FACW supplementation on endogenous glucose production.

Plasma insulin concentration was increased with FACW supplementation. It is possible that increased insulin concentration was a result of increased plasma glucose concentration or ruminal propionate during the postpartum period, as both are known to stimulate insulin secretion without decreasing hepatic glucose production in ruminants (Harmon, 1992; Smith et al., 2007; Aschenbach et al., 2010). Fermentation of FACW increased propionate production in vitro (Wagner et al., 2018) and there was marginal evidence for increased rumen molar proportion of propionate in the current experiment at 7 DIM. This potential for an increase in propionate supply may have stimulated an increase in insulin secretion in the current experiment; however, more intensive sampling during the initiation of dietary treatment would be necessary to verify that propionate production was increased rapidly enough to account for the increased insulin after treatment initiation postpartum. Regardless of the stimulatory factor, insulin is known to inhibit lipolysis in adipose tissue (Bell, 1981). As a consequence, the increased plasma insulin concentration may have mediated the decreased plasma NEFA concentration in early lactation dairy cows supplemented with FACW compared with control cows. Decreased lipolysis could have resulted in decreased supply of fatty acids for hepatic oxidation, thereby decreasing the likelihood of incomplete oxida- 
tion of acetyl $\mathrm{CoA}$ and potentially contributing to the decrease in plasma BHB concentrations in the immediate postpartum period for FACW-supplemented cows.

Our hypothesis that the metabolism of FACW through lactate and propionate would increase the availability of intermediates of the TCA cycle in liver, resulting in decreased formation of BHB by hepatocytes, appears to be indirectly substantiated. Although the current experiment did not demonstrate a reduction in circulating BHB concentration after the first week postpartum, this experimental design did not allow for quantification of rumen butyrate contribution to circulating BHB concentration. It is possible that the increased molar proportion of butyrate observed in rumen fluid of cows supplemented with FACW represents an increase in rumen butyrate production. Increased rumen butyrate production could have contributed to plasma BHB concentrations, confounding the potential reductions in plasma BHB reflective of improvements in hepatic fatty acid oxidation after the first week postpartum. The effect of rumen infused butyrate on increasing plasma BHB has been demonstrated previously (Herrick et al., 2018) and reflects partial oxidation of butyrate to BHB within the rumen epithelium. Subsequent work exploring hepatic oxidative capacity could provide additional insights. The decrease in plasma BHB concentrations in the immediate postpartum period for FACW-supplemented cows may have contributed to the marginally significant reduction of 23 percentage units in HYK incidence. Unfortunately, this experiment was not designed to be adequately powered for binary hypothesis testing on binary response variables such as HYK incidence; thus, additional research on larger cohorts of animals, with or without metabolic challenge, are still needed to fully understand the effect of FACW supplementation on HYK incidence.

\section{CONCLUSIONS}

Supplementation with FACW resulted in improved feed efficiency as assessed by measures of milk output relative to feed intake given that DMI was reduced without detected effects on milk yield, milk protein yield, and milk energy output. Postpartum supplementation with FACW increased plasma glucose and insulin concentration, with the latter potentially having mediated reductions in plasma NEFA immediately postpartum. The decreased plasma BHB concentration immediately postpartum in cows supplemented with FACW compared with control may have reduced HYK incidence for FACW-supplemented cows. The improvements in plasma metabolite profile immediately postpartum may have been mediated by increasing gluconeogenic precursors provided to the liver from the FACW diet.

\section{ACKNOWLEDGMENTS}

The GlucoBoost product and funding for this research were provided by Fermented Nutrition Corporation. Partial support was also provided by USDA Hatch grant number WIS01877 from the Wisconsin Agricultural Experiment Station (Madison). The authors thank Jessica Cederquist, dairy herd administrator, and the University of Wisconsin-Madison Dairy Cattle Instruction and Research Center staff for their support and assistance. We also thank our colleagues Tyler Mack, Kristina Weld, Sophia Erb, and Tawny Chandler (University of Wisconsin, Madison) for their support and cooperation during this study.

\section{REFERENCES}

Allen, M. S., B. J. Bradford, and M. Oba. 2009. Board invited review: The hepatic oxidation theory of the control of feed intake and its application to ruminants. J. Anim. Sci. 87:3317-3334. https://doi .org/10.2527/jas.2009-1779.

AOAC International. 1996. Official Methods of Analysis. 15th ed. AOAC International, Arlington, VA.

AOAC International. 2012. Official Methods of Analysis. 19th ed. AOAC International, Arlington, VA.

Arriola Apelo,, S. I., J. R. Knapp, and M. D. Hanigan. 2014. Invited review: Current representation and future trends of predicting amino acid utilization in the lactating dairy cow. J. Dairy Sci. 97:4000-4017. https://doi.org/10.3168/jds.2013-7392.

Aschenbach, J. R., N. B. Kristensen, S. S. Donkin, H. M. Hammon, and G. B. Penner. 2010. Gluconeogenesis in dairy cows: The secret of making sweet milk from sour dough. IUBMB Life 62:869-877. https://doi.org/10.1002/iub.400.

Aschenbach, J. R., G. B. Penner, F. Stumpff, and G. Gabel. 2011. Ruminant nutrition symposium: Role of fermentation acid absorption in the regulation of ruminal pH. J. Anim. Sci. 89:1092-1107. https: //doi.org/10.2527/jas.2010-3301.

Bach Knudsen, K. E. 1997. Carbohydrate and lignin contents of plant materials used in animal feeding. Anim. Feed Sci. Technol. 67:319 338. https://doi.org/10.1016/S0377-8401(97)00009-6.

Bal, M. A., R. D. Shaver, A. G. Jirovec, K. J. Shinners, and J. G. Coors. 2000. Crop processing and chop length of corn silage: Effects on intake, digestion, and milk production by dairy cows. J. Dairy Sci. 83:1264-1273. https://doi.org/10.3168/jds.S0022 -0302(00)74993-9.

Baldwin, R. L., W. A. Wood, and R. S. Emery. 1962. Conversion of lactate-C14 to propionate by the rumen microflora. J. Bacteriol. 83:907-913.

Bell, A. W. 1981. Lipid metabolism in liver and selected tissues and in the whole body of ruminant animals. Pages 363-410 in Lipid Metabolism in Ruminant Animals. Elsevier, Philadelphia, PA.

Bello, N. M., and D. G. Renter. 2018. Invited review: Reproducible research from noisy data: Revisiting key statistical principles for the animal sciences. J. Dairy Sci. 101:5679-5701. https://doi.org/ 10.3168/jds.2017-13978

Brossard, L., C. Martin, F. Chaucheyras-Durand, and B. MichaletDoreau. 2004. Protozoa involved in butyric rather than lactic fermentative pattern during latent acidosis in sheep. Reprod. Nutr. Dev. 44:195-206. https://doi.org/10.1051/rnd:2004023.

Chandler, T. L., R. S. Pralle, J. R. R. Dorea, S. E. Poock, G. R. Oetzel, R. H. Fourdraine, and H. M. White. 2018. Predicting hyperketonemia by logistic and linear regression using test-day milk and performance variables in early-lactation Holstein and Jersey cows. J. Dairy Sci. 101:2476-2491. https://doi.org/10.3168/jds .2017-13209. 
Derias, R. 1961. Method for determination water soluble carbohydrates. J. Sci. Food Agric. 12:152.

Douglas, G. N., T. R. Overton, H. G. Bateman, H. M. Dann, and J. K. Drackley. 2006. Prepartal plane of nutrition, regardless of dietary energy source, affects periparturient metabolism and dry matter intake in Holstein cows. J. Dairy Sci. 89:2141-2157. https://doi .org/10.3168/jds.S0022-0302(06)72285-8.

Drackley, J. K. 1999. Biology of dairy cows during the transition period: The final frontier? J. Dairy Sci. 82:2259-2273. https://doi .org/10.3168/jds.S0022-0302(99)75474-3.

Gualdrón-Duarte, L. B., and M. S. Allen. 2017. Increased anaplerosis of the tricarboxylic acid cycle decreased meal size and energy intake of cows in the postpartum period. J. Dairy Sci. 100:44254434. https://doi.org/10.3168/jds.2016-12104.

Gualdrón -Duarte, L. B., and M. S. Allen. 2018. Fuels derived from starch digestion have different effects on energy intake and metabolic responses of cows in the postpartum period. J. Dairy Sci. https://doi.org/10.3168/jds.2017-13607.

Harmon, D. L. 1992. Impact of nutrition on pancreatic exocrine and endocrine secretion in ruminants: A review. J. Anim. Sci. 70:12901301. https://doi.org/10.2527/1992.7041290x.

Herdt, T. H. 2000. Ruminant adaptation to negative energy balance. Vet. Clin. North Am. Food Anim. Pract. 16:215-230. https://doi .org/10.1016/s0749-0720(15)30102-x.

Herrick, K. J., A. R. Hippen, K. F. Kalscheur, D. J. Schingoethe, S. D. Ranathunga, J. L. Anderson, S. C. Moreland, and J. E. van Eys. 2018. Infusion of butyrate affects plasma glucose, butyrate, and beta-hydroxybutyrate but not plasma insulin in lactating dairy cows. J. Dairy Sci. 101:3524-3536. https://doi.org/10.3168/jds 2017-13842.

Hino, T., and S. Kuroda. 1993. Presence of lactate dehydrogenase and lactate racemase in Megasphaera elsdenii grown on glucose or lactate. Appl. Environ. Microbiol. 59:255-259.

Hippen, A. R., P. She, J. W. Young, D. C. Beitz, G. L. Lindberg, L. F. Richardson, and R. W. Tucker. 1999. Alleviation of fatty liver in dairy cows with 14-day intravenous infusions of glucagon. J. Dairy Sci. 82:1139-1152. https://doi.org/10.3168/jds.S0022 -0302(99)75337-3.

Janovick, N. A., Y. R. Boisclair, and J. K. Drackley. 2011. Prepartum dietary energy intake affects metabolism and health during the periparturient period in primiparous and multiparous Holstein cows. J. Dairy Sci. 94:1385-1400. https://doi.org/10.3168/jds.2010 $-3303$.

Mackle, T., D. Dwyer, K. L. Ingvartsen, P. Chouinard, D. Ross, and D. Bauman. 2000. Effects of insulin and postruminal supply of protein on use of amino acids by the mammary gland for milk protein synthesis. J. Dairy Sci. 83:93-105. https://doi.org/10.3168/ jds.S0022-0302(00)74860-0.

Maldini, G., and M. S. Allen. 2018. Temporal effects of ruminal propionic acid infusion on feeding behavior of Holstein cows in the postpartum period. J. Dairy Sci. 101:3077-3084. https://doi.org/ $10.3168 /$ jds.2017-13857.

McArt, J. A. A., D. V. Nydam, and G. R. Oetzel. 2012. Epidemiology of subclinical ketosis in early lactation dairy cattle. J. Dairy Sci. 95:5056-5066. https://doi.org/10.3168/jds.2012-5443.

Mertens, D. R. 2002. Gravimetric determination of amylase-treated neutral detergent fiber in feeds with refluxing in beakers or crucibles: Collaborative study. J. AOAC Int. 85:1217-1240.

Nagaraja, T. G., and E. C. Titgemeyer. 2007. Ruminal acidosis in beef cattle: The current microbiological and nutritional outlook. J. Dairy Sci. 90(Suppl 1):E17-E38. https://doi.org/10.3168/jds.2006 -478 .

NRC. 2001. Nutrient Requirements of Dairy Cattle. 7th rev. ed. Natl. Acad. Press, Washington, DC.

Newbold, C. J., A. G. Williams, and D. G. Chamberlain. 1987. The in vitro metabolism of $\mathrm{D}$, L-lactic acid by rumen microorganisms. J. Sci. Food Agric. 38:9-18. https://doi.org/10.1002/jsfa.2740380104.

Oetzel, G. R. 2004. Monitoring and testing dairy herds for metabolic disease. Vet. Clin. North Am. Food Anim. Pract. 20:651-674. https://doi.org/10.1016/j.cvfa.2004.06.006.
Penner, G. B., J. R. Aschenbach, G. Gäbel, and M. Oba. 2009a. Technical note: Evaluation of a continuous ruminal $\mathrm{pH}$ measurement system for use in noncannulated small ruminants. J. Anim. Sci. 87:2363-2366. https://doi.org/10.2527/jas.2008-1665.

Penner, G. B., J. R. Aschenbach, G. Gabel, R. Rackwitz, and M. Oba. 2009b. Epithelial capacity for apical uptake of short chain fatty acids is a key determinant for intraruminal $\mathrm{pH}$ and the susceptibility to subacute ruminal acidosis in sheep. J. Nutr. 139:1714-1720. https://doi.org/10.3945/jn.109.108506.

Plaizier, J. C., D. O. Krause, G. N. Gozho, and B. W. McBride. 2008. Subacute ruminal acidosis in dairy cows: the physiological causes, incidence and consequences. Vet. J. 176:21-31. https://doi.org/10 $.1016 / j . t v j l .2007 .12 .016$.

Prabhu, R., E. Altman, and M. A. Eiteman. 2012. Lactate and acrylate metabolism by Megasphaera elsdenii under batch and steadystate conditions. Appl. Environ. Microbiol. 78:8564-8570. https:// doi.org/10.1128/AEM.02443-12.

Pralle, R. S., R. C. Oliveira, T. L. Chandler, S. J. Bertics, and H. M. White. 2015. Hepatic patatin-like phospholipase domain-containing protein 3 protein is regulated during the transition to lactation period in dairy cows. J. Dairy Sci. 98(Suppl. 2):10. (Abstr.)

Pralle, R. S., K. W. Weigel, and H. M. White. 2018. Predicting blood $\beta$-hydroxybutyrate using milk Fourier transform infrared spectrum, milk composition, and producer-reported variables with multiple linear regression, partial least squares regression, and artificial neural network. J. Dairy Sci. 101:4378-4387. https://doi .org/10.3168/jds.2017-14076.

Qumar, M., R. Khiaosa-Ard, P. Pourazad, S. U. Wetzels, F. Klevenhusen, W. Kandler, J. R. Aschenbach, and Q. Zebeli. 2016. Evidence of in vivo absorption of lactate and modulation of short chain fatty acid absorption from the reticulorumen of non-lactating cattle fed high concentrate diets. PLoS One 11:e0164192. https://doi.org/10 .1371/journal.pone.0164192.

Rathbun, F. M., R. S. Pralle, S. J. Bertics, L. E. Armentano, K Cho, C. Do, K. A. Weigel, and H. M. White. 2017. Relationships between body condition score change, prior mid-lactation phenotypic residual feed intake, and hyperketonemia onset in transition dairy cows. J. Dairy Sci. 100:3685-3696. https://doi.org/10.3168/ jds.2016-12085.

Resende Júnior, J. C., M. N. Pereira, H. Bôer, and S. Tamminga. 2006 Comparison of techniques to determine the clearance of ruminal volatile fatty acids. J. Dairy Sci. 89:3096-3106. https://doi.org/10 $.3168 /$ jds.S0022-0302(06)72584-X.

Rutherford, A. J., G. Oikonomou, and R. F. Smith. 2016. The effect of subclinical ketosis on activity at estrus and reproductive performance in dairy cattle. J. Dairy Sci. 99:4808-4815. https://doi.org/ $10.3168 /$ jds. $2015-10154$.

Sailer, K., R. Pralle, R. Oliveira, S. Erb, G. Oetzel, and H. White. 2018. Validation of the BHBCheck blood $\beta$-hydroxybutyrate meter as a diagnostic tool for hyperketonemia in dairy cows. J. Dairy Sci. 101:1524-1529. https://doi.org/10.3168/jds.2017-13583.

Santschi, D. E., R. Lacroix, J. Durocher, M. Duplessis, R. K. Moore, and D. M. Lefebvre. 2016. Prevalence of elevated milk beta-hydroxybutyrate concentrations in Holstein cows measured by Fourier-transform infrared analysis in Dairy Herd Improvement milk samples and association with milk yield and components. J. Dairy Sci. 99:9263-9270. https://doi.org/10.3168/jds.2016-11128.

Schirmann, K., M. A. von Keyserlingk, D. Weary, D. Veira, and W. Heuwieser. 2009. Validation of a system for monitoring rumination in dairy cows. J. Dairy Sci. 92:6052-6055. https://doi.org/10 $.3168 /$ jds.2009-2361.

Schwaiger, T., K. A. Beauchemin, and G. B. Penner. 2013. Duration of time that beef cattle are fed a high-grain diet affects the recovery from a bout of ruminal acidosis: Short-chain fatty acid and lactate absorption, saliva production, and blood metabolites. J. Anim. Sci. 91:5743-5753. https://doi.org/10.2527/jas.2013-6472.

Shreve, B., N. Thiex, and M. Wolf. 2006. National forage testing association reference method: dry matter by oven drying for 3 hours at 105 C. NFTA Reference Methods. National Forage Testing Association, Omaha, NE. 
Smith, K. L., S. E. Stebulis, M. R. Waldron, and T. R. Overton. 2007. Prepartum 2,4-thiazolidinedione alters metabolic dynamics and dry matter intake of dairy cows. J. Dairy Sci. 90:3660-3670. https: //doi.org/10.3168/jds.2006-650.

Suthar, V. S., J. Canelas-Raposo, A. Deniz, and W. Heuwieser. 2013. Prevalence of subclinical ketosis and relationships with postpartum diseases in European dairy cows. J. Dairy Sci. 96:2925-2938. https://doi.org/10.3168/jds.2012-6035.

Tyrrell, H., and P. Moe. 1975. Effect of intake on digestive efficiency. J. Dairy Sci. 58:1151-1163. https://doi.org/10.3168/jds.S0022 -0302(75)84694-7.

Wagner, B. K., B. A. Wenner, J. E. Plank, G. D. Poppy, and J. L. Firkins. 2018. Investigation of ammonium lactate supplementation on fermentation end products and bacterial assimilation of nitrogen in dual-flow continuous culture. J. Dairy Sci. https://doi.org/10 $.3168 /$ jds.2017-14358.

Weimer, P. J., Y. Shi, and C. L. Odt. 1991. A segmented gas/liquid delivery system for continuous culture of microorganisms on in- soluble substrates and its use for growth of Ruminococcus flavefaciens on cellulose. Appl. Environ. Microbiol. 36:178-183. https:// doi.org/10.1007/bf00164416.

White, H. M. 2015. The role of TCA cycle anaplerosis in ketosis and fatty liver in periparturient dairy cows. Animals (Basel) 5:793-802.

Wildman, E. E., G. M. Jones, P. E. Wagner, R. L. Boman, H. F. Troutt, and T. N. Lesch. 1982. A dairy cow body condition scoring system and its relationship to selected production characteristics. J. Dairy Sci. 65:495-501. https://doi.org/10.3168/jds.S0022 $-0302(82) 82223-6$.

Zebeli, Q., J. Dijkstra, M. Tafaj, H. Steingass, B. N. Ametaj, and W. Drochner. 2008. Modeling the adequacy of dietary fiber in dairy cows based on the responses of ruminal $\mathrm{pH}$ and milk fat production to composition of the diet. J. Dairy Sci. 91:2046-2066. https: //doi.org/10.3168/jds.2007-0572. 